\title{
Asymmetric intermediate reflector for tandem micromorph thin film silicon solar cells
}

\author{
T. Söderström, ${ }^{\text {a) }}$ F.-J. Haug, X. Niquille, V. Terrazzoni, and C. Ballif \\ Photovoltaics and Thin Film Electronics Laboratory, Institute of Microengineering, Ecole Polytechnique \\ Fédérale de Lausanne (EPFL), Rue A.-L. Breguet 2, CH-2000 Neuchâtel, Switzerland
}

(Received 19 December 2008; accepted 15 January 2009; published online 9 February 2009)

\begin{abstract}
The micromorph solar cell (stack of amorphous and microcrystalline cells) concept is the key for achieving high efficiency stabilized thin film silicon solar cells. We introduce a device structure that allows a better control of the light in-coupling into the two subcell components. It is based on an asymmetric intermediate reflector, which increases the effective thickness of the $a-\mathrm{Si}: \mathrm{H}$ by a factor of more than three. Hence, the $a-\mathrm{Si}: \mathrm{H}$ thickness reduction diminishes the light induced degradation, and micromorph tandem cells with $11.2 \%$ initial and $9.8 \%$ stabilized efficiencies $\left(1000 \mathrm{~h}, 50{ }^{\circ} \mathrm{C}\right.$, and $100 \mathrm{~mW} / \mathrm{cm}^{2}$ ) are made on plastic substrates with $T_{g}<180{ }^{\circ} \mathrm{C}$. (C) 2009 American Institute of Physics. [DOI: 10.1063/1.3079414]
\end{abstract}

Thin film silicon solar cells are promising candidates for low cost photovoltaic energy. ${ }^{1}$ The efficiencies of single junction thin film silicon solar cells are continuously increasing. ${ }^{2}$ Nonetheless, the energy band gap of the absorber layer determines both the maximum voltage and the maximum quantity of light absorption, and their inherent correlation limits the maximum conversion efficiency of single junction solar cells. ${ }^{3}$ The concept for avoiding the trade off between voltage and absorption is the introduction of tandem cells with different energy band gaps. Therefore, the micromorph tandem solar cells, ${ }^{4}$ composed of an amorphous $(a-\mathrm{Si}: \mathrm{H})$ top cell and a microcrystalline $(\mu \mathrm{c}-\mathrm{Si}: \mathrm{H})$ bottom cell, are key for achieving high efficiency stabilized thin film silicon solar cells. The challenge with this tandem structure is to increase the short circuit current densities $\left(J_{\mathrm{sc}}\right)$ in both cells while keeping a thin top absorber in order to limit the light induced degradation. ${ }^{5}$ One widely used solution in the superstrate configuration $(p-i-n)$ is to introduce a thin intermediate reflector (IR) ${ }^{6}$ which enhances the $J_{\text {sc }}$ of the top cell without the need of increasing its absorber layer thickness. The IR has a lower index of refraction $\left(1.5<n_{\mathrm{IR}}\right.$ $<2.2)$ than $\mathrm{Si}\left(n_{\mathrm{Si}} \sim 4\right)$ and reflects the light in the top cell. In situ IRs made from silicon oxide (SOIR) (Ref. 7) or silicon nitride ${ }^{8}$ and ex situ zinc oxide IRs (Ref. 9) have been reported to be very effective and are already implemented in complete products. ${ }^{10}$ Nonetheless in the substrate configuration $(n-i-p)$ useful for opaque substrate, the problem of high efficiency micromorph tandems with elevated $J_{\mathrm{sc}}$ in the top cell is not yet solved because of the difficulties involved in obtaining high $J_{\mathrm{sc}}$ in both subcell components. The solution so far has been triple junction solar cells with low band gap $a$-SiGe where the absorption is distributed into three thin cells. ${ }^{11}$ However, such devices are more complex. In this paper, we consider the simpler case of two junctions, and we introduce an asymmetric IR (AIR), which allows one to separate the in-coupling of the light between the two subcells of $n-i-p$ micromorph tandem solar cells.

Enhanced absorption in $a-\mathrm{Si}: \mathrm{H}$ and $\mu \mathrm{c}-\mathrm{Si}: \mathrm{Ha}$ and production throughput require the implementation of light trap-

${ }^{a)}$ Electronic mail: thomas.soderstrom @epfl.ch. ping schemes in thin film silicon devices. This is usually performed by scattering of the light by a texture at the optical interfaces of the device. This scattering occurs when the effective wavelength corresponds to the feature size of the texture, and a difficulty arises from the wide spectral range of absorption of the tandem cells $(350-1100 \mathrm{~nm})$ and from the fact that the light trapping regions for the two subcells are different. Furthermore, the ideal structure for the growth of $\mu \mathrm{c}-\mathrm{Si}: \mathrm{H}$ solar cell has a texture with soft or $\mathrm{U}$ shape morphology and feature size larger than $1 \mu \mathrm{m},{ }^{12}$ whereas the top cell is usually less sensitive to the substrate morphology and requires a feature size around $300 \mathrm{~nm} .{ }^{13}$ An unwanted effect in the $n-i-p$ micromorph tandem is that the deposition of $\mu \mathrm{c}-\mathrm{Si}: \mathrm{H}$ material flattens the initial substrate texture, which reduces the amount of light scattering in the top cell, allowing only one single passage through the amorphous cell as shown in Fig. 1(a). The symmetric or standard IR (SIR) [Fig. 1(b)] increases the light absorption in the top cell, but since its interfaces are flat, only specular reflections occur on the SIR and therefore its performances are limited. The AIR proposed in Fig. 1(c) offers the possibility of splitting the light trapping schemes effective in the two subcells. In fact, the AIR restores and even adapts the texture to the ideal mor-

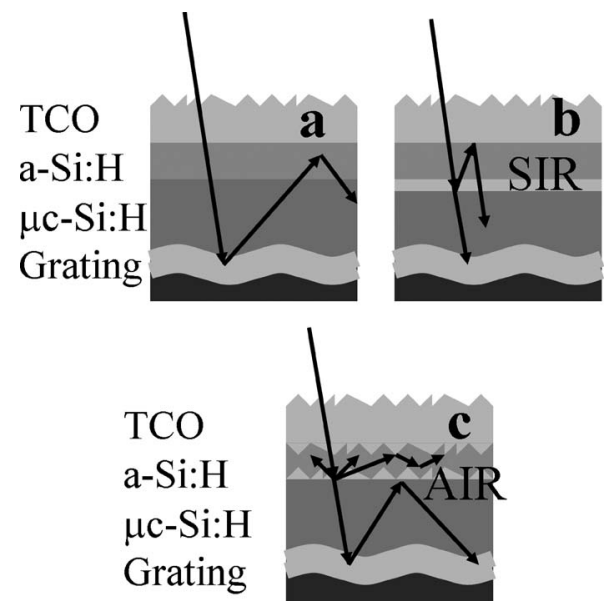

FIG. 1. Design of $n-i-p$ micromorph without IR (a), with SIR (b), and with AIR (c). 


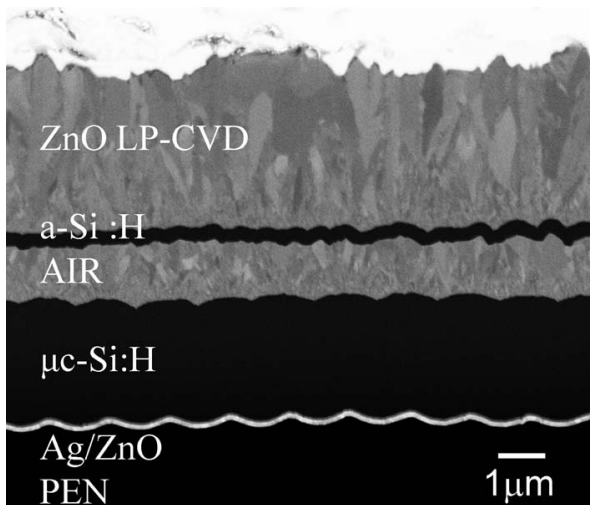

FIG. 2. SEM micrographs of $n-i-p$ micromorph solar cell with AIR between the top and bottom cells. The cell is deposited on PEN plastic foil.

phology for the $a$-Si:H top cell. The scattering effects at the AIR/Si interfaces provide the optimum light in-coupling into the top $a-\mathrm{Si}: \mathrm{H}$ solar cells and thus boost the stabilized tandem solar cells efficiencies, thanks to the thinning down of the $a-\mathrm{Si}: \mathrm{H}$ cell.

Two back contacts for $n-i$ - $p$ micromorph tandem solar cells on glass substrate for reference and on plastic substrates are presented in this paper. The solar cell shown in Fig. 2 is deposited on polyethylene naphthalate (PEN) plastic foil structured with a periodic sinusoidal two-dimensional crossgrating with periodicity of $1.2 \mu \mathrm{m}$. Then, the back contact is covered with $80 \mathrm{~nm}$ of silver and $60 \mathrm{~nm}$ of $\mathrm{ZnO}$ deposited by sputtering at room temperature. The solar cell on glass (Schott AF45) are covered with hot silver ${ }^{14}$ deposited by sputtering at elevated temperature and $60 \mathrm{~nm}$ thin $\mathrm{ZnO}$ used for optical matching and as a barrier layers. ${ }^{15}$ On top of the back contact, a $2.8 \mu \mathrm{m}$ thick $\mu \mathrm{c}-\mathrm{Si}: \mathrm{H}$ bottom cell is deposited. Then the AIR consists of $1.6 \mu \mathrm{m}$ of zinc oxide $(\mathrm{ZnO})$ deposited by low pressure chemical vapor deposition (LP-CVD), which results in a naturally textured growth ${ }^{16}$ with typical lateral size of $300 \mathrm{~nm}$. Finally, a $180 \mathrm{~nm}$ thick $a-\mathrm{Si}: \mathrm{H}$ top cell and a transparent front contact of $3.8 \mu \mathrm{m}$ of LP-CVD ZnO is grown. The silicon layers are deposited by very high frequency plasma enhanced CVD. The electrode excitation frequency is $70 \mathrm{MHz}$, the deposition temperature is $200{ }^{\circ} \mathrm{C}$, and the main gases for the deposition are silane $\left(\mathrm{SiH}_{4}\right)$, hydrogen $\left(\mathrm{H}_{2}\right)$, and methane $\left(\mathrm{CH}_{4}\right)$. Phosphine $\left(\mathrm{PH}_{3}\right)$ and trimethylboron are added for the $n$ and $p$ doped layers, respectively. The typical cell size is $0.25-0.5 \mathrm{~cm}^{2}$. The total reflection $(R)$ from the solar cells is measured with a photospectrometer (Perkin Elmer lambda 900) with integrationsphere within a spectral range of $400-2000 \mathrm{~nm}$. The $J_{\text {sc }}$ is calculated from the external quantum efficiency (EQE) measurement by convolution with the AM1.5g solar spectrum and integration over the wavelength range of 400-1100 nm. The current-voltage $(J-V)$ measurements are performed at $25{ }^{\circ} \mathrm{C}$ with a class A solar simulator (Wacom WXS-140S$10)$. From that $J-V$ curve the $V_{\text {oc }}$ and fill factor (FF) are obtained, and the $J_{\mathrm{sc}}$ is adjusted to the one found through the EQE. This method avoids uncertainties in the determination of the solar cell surface area. The cells are stabilized by light soaking under $V_{\text {oc }}$ conditions for $1000 \mathrm{~h}$ at $50^{\circ}$ and $50-100 \mathrm{~mW} / \mathrm{cm}^{2}$.

The structure is designed with the aim of having a soft or $\mathrm{U}$ shape morphology texture, which preserves the quality of the $\mu \mathrm{c}-\mathrm{Si}: \mathrm{H}$ material, with large feature size that can effi-

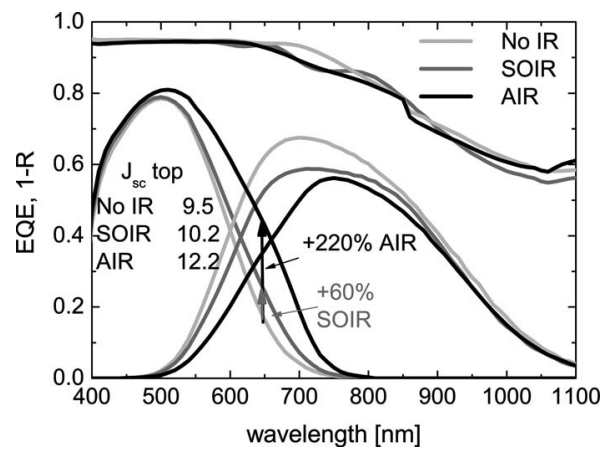

FIG. 3. EQE and reflection $(1-R)$ of micromorph tandem cell with $200 \mathrm{~nm}$ thick $a$-Si:H cells without IR, with SIR (SOIR), and with AIR deposited on glass covered with hot silver.

ciently scatter the red light between 750 and $1000 \mathrm{~nm}$ in the thick $\mu \mathrm{c}-\mathrm{Si}: \mathrm{H}$ layer. Then, the $\mathrm{ZnO}$ AIR has random textured morphology, which scatters efficiently the blue-green light in the thin $a-\mathrm{Si}: \mathrm{H}$ top cell, as described in Fig. 1. Figure 3 compares the effect of the three IRs in the EQE of $200 \mathrm{~nm}$ thick $a$-Si:H top cells, without IR, with SIR $(100 \mathrm{~nm}$ of SOIR, $\left.n_{\text {SOIR }}=2\right)$, and with AIR (1.5 $\mu$ m of LP-CVD ZnO, $\left.n_{\mathrm{AIR}}=1.8\right)$. The $J_{\mathrm{sc}}$ of the top cell increases with the introduction of the SIR by an absolute $0.7 \mathrm{~mA} / \mathrm{cm}^{2}$, whereas the AIR increases the $J_{\mathrm{sc}}$ by $2.7 \mathrm{~mA} / \mathrm{cm}^{2}$. At $650 \mathrm{~nm}$, the relative gain in the EQE is $60 \%$ for the SOIR and $220 \%$ for the AIR. The effectiveness of the AIR configuration is related to its well adapted texture. Indeed, Fig. 2 shows that $\mu \mathrm{c}-\mathrm{Si}: \mathrm{H}$ smoothens the interface with the IR and that the surface structure is not suited for inducing any light trapping in the $a-\mathrm{Si}: \mathrm{H}$ top cell. The AIR restores a random roughness, which creates favorable light scattering for $a-\mathrm{Si}: \mathrm{H}$ solar cells ${ }^{17}$ since light is both scattered and reflected. A part of the weakly absorbed light that is reflected by the AIR is also out-coupled from the device. This effect is shown in Fig. 4 where the reflection from a micromorph tandem cell with AIR is increased between 550 and $900 \mathrm{~nm}$ compared to cell without IR. By integrating the difference in reflection, we estimate losses of around $0.5 \mathrm{~mA} / \mathrm{cm}^{2}$ due to this reflection effect, which is a loss of only $2 \%$ with a total $J_{\mathrm{sc}}$ of $25 \mathrm{~mA} / \mathrm{cm}^{2}$. Therefore, including the AIR is almost loss free as also shown in Fig. 4 where the total $J_{\text {sc }}$ of $3 \mu \mathrm{m}$ $\mu \mathrm{c}-\mathrm{Si}-\mathrm{H}$ is equivalent to the sum of $J_{\mathrm{sc}}$ of a tandem micromorph with $3 \mu \mathrm{m}$ thick bottom cell. The AIR increases the effective thicknesses of the $a-\mathrm{Si}: \mathrm{H}$ layer, which is crucial for

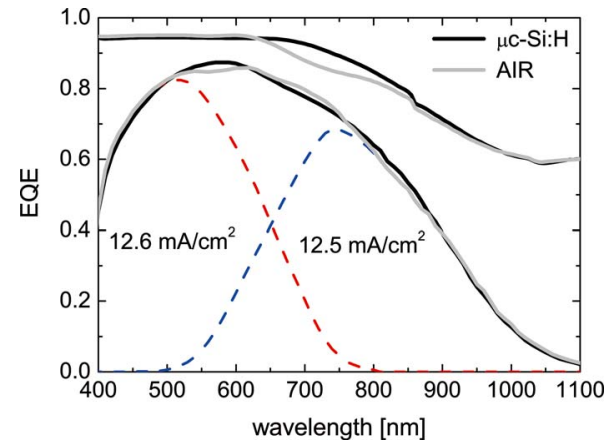

FIG. 4. (Color online) Reflections $(1-R)$ plotted in the upper part compared with micromorph tandem cells with AIR (gray line) and without AIR (black line) deposited on glass substrates. EQEs compared with micromorph tandem cells with AIR (gray line) and single $\mu \mathrm{c}-\mathrm{Si}: \mathrm{H}$ (black line) solar cells with $3 \mu \mathrm{m}$ thick absorber layers deposited on plastic foils. 
TABLE I. Performance parameters of $n-i-p$ micromorph tandem cells deposited on glass substrate with and without AIR (stabilized parameters are given in brackets). Both cells have been exposed to light soaking for $1000 \mathrm{~h}$ at $50 \mathrm{~mW} / \mathrm{cm}^{2}$.

\begin{tabular}{lcccccc}
\hline \hline $\begin{array}{c}\text { Thickness } a-\mathrm{Si} / \mu \mathrm{c}-\mathrm{Si} \\
(\mu \mathrm{m})\end{array}$ & $\begin{array}{c}\mathrm{V}_{\mathrm{oc}} \\
(\mathrm{mV})\end{array}$ & $\begin{array}{c}\mathrm{FF} \\
(\%)\end{array}$ & $\begin{array}{c}J_{\text {top }} \\
\left(\mathrm{mA} / \mathrm{cm}^{2}\right)\end{array}$ & $\begin{array}{c}J_{\text {bottom }} \\
\left(\mathrm{mA} / \mathrm{cm}^{2}\right)\end{array}$ & $\begin{array}{c}\text { Efficiency } \\
(\%)\end{array}$ & $\begin{array}{c}\text { Deg. } \\
(\%)\end{array}$ \\
\hline $0.3 / 1.2$ (no IR) & $1.35(1.34)$ & $73(62)$ & $10.7(10.3)$ & $11.5(11.2)$ & $10.5(8.6)$ & 18 \\
$0.14 / 1.4$ (AIR) & $1.32(1.35)$ & $74(69)$ & $11.4(10.5)$ & $10.6(10.2)$ & $10.4(9.5)$ & 8 \\
\hline \hline
\end{tabular}

the light induced degradation of the $a$-Si: $\mathrm{H}$ cell and thus the micromorph tandem cell. Indeed in Table I, the typical degradation is $18 \%$ for a top cell of $300 \mathrm{~nm}$, whereas the degradation is limited to $8 \%$ for the cell with $140 \mathrm{~nm}$ and the AIR. Therefore for the same absorbing light in the tandem device, the AIR increases the stable performances relatively by $10 \%$ for $n-i-p$ device, thanks to the thinner top $a-\mathrm{Si}: \mathrm{H}$ solar cell. Another advantage of the $n-i-p$ configuration is its applicability to flexible substrates. The next results focus on $n-i-p$ micromorph tandem cells on PEN low $T_{g}\left(<180{ }^{\circ} \mathrm{C}\right)$ foil as substrate. Using the concept of the AIR shown in Fig. 2 , we made a micromorph $n-i-p$ solar cell with initial efficiency of $11.2 \%\left(1.34 \mathrm{~V}, 68 \%, 12.3 \mathrm{~mA} / \mathrm{cm}^{2}\right)$, which stabilizes at an efficiency of $9.8 \%\left(1.35 \mathrm{~V}, 64 \%, 11.9 \mathrm{~mA} / \mathrm{cm}^{2}\right)$ after $1000 \mathrm{~h}$ of light soaking at $V_{\mathrm{oc}}, 50{ }^{\circ} \mathrm{C}$ and $100 \mathrm{~mW} / \mathrm{cm}^{2}$. The initial and stable $J(V)$ curves are shown in Fig. 5.

The idea of having a double structure with a diffractive interlayer was proposed by numerical calculation for the $p$-i-n configuration by Obermeyer et al. ${ }^{18}$ Nevertheless, the technological tools are not yet available for this complex $p-i-n$ design. Our AIR in the $n-i-p$ configuration avoids the technological challenges, which are limiting the $p-i-n$ devices, and it offers an alternative to the complex triple junction devices.

In summary, we have fully implemented an AIR that selectively scatters the blue-green light into the top cell,

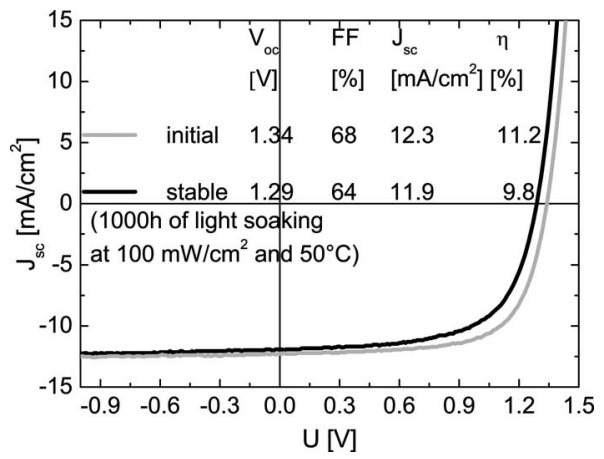

FIG. 5. $J(V)$ curves of initial and stabilized $n-i-p$ micromorph tandem with AIR deposited on plastic substrates. whereas the scattering of the red light into the bottom cell is achieved by the back reflector structure, which is applied to the substrate. Such a structure can reach matched $J_{\mathrm{sc}}$ up to almost $12 \mathrm{~mA} / \mathrm{cm}^{2}$ in the stabilized state, which is a necessary starting point for realizing $12 \%$ stable efficiencies in micromorph tandem cells on low $T_{g}$ plastic substrates (assuming $V_{\mathrm{oc}}$ of $1.4 \mathrm{~V}$ and FF of $71 \%$ ).

The authors gratefully acknowledge support by the Swiss Federal Energy Office (OFEN) under Grant No. 101191.

${ }^{1}$ A. Shah, P. Torres, R. Tscharner, N. Wyrsch, and H. Keppner, Science 285, 692 (1999).

${ }^{2}$ Y. Mai, S. Klein, R. Carius, J. Wolff, A. Lambertz, F. Finger, and X. Geng, J. Appl. Phys. 97, 114913 (2005).

${ }^{3}$ W. Shockley and H. Queisser, J. Appl. Phys. 32, 510 (1961).

${ }^{4} J$. Meier, S. Dubail, S. Golay, U. Kroll, S. Fay, E. Vallat-Sauvain, L. Feitknecht, J. Dubail, and A. Shah, Sol. Energy Mater. Sol. Cells 74, 457 (2002)

${ }^{5}$ D. L. Staebler and C. R. Wronski, Appl. Phys. Lett. 31, 292 (1977).

${ }^{6}$ D. Fischer, S. Dubail, J. A. Anna Selvan, N. Pellaton Vaucher, R. Platz, C. Hof, U. Kroll, J. Meier, P. Torres, H. Keppner, N. Wyrsch, M. Goetz, A Shah, and K.-D. Ufet, Proceedings of the 25th IEEE PVSC, 1996 (unpublished).

${ }^{7}$ D. Dominé, P. Buehlmann, J. Bailat, A. Billet, A. Feltrin, and C. Ballif, Phys. Status Solidi (RRL) 2, 163 (2008).

${ }^{8}$ P. D. Vineri, L. V. Mercaldo, I. Usatii, P. Ciani, and C. Privato, Proceedings of the 23rd European PVSEC, 2008 (unpublished).

${ }^{9}$ D. Dominé, J. Bailat, J. Steinhauser, A. Shah, and C. Ballif, Proceedings of the 4th World WCPEC, 2006 (unpublished).

${ }^{10}$ K. Yamamoto, A. Nakajima, M. Yoshimi, T. Sawada, S. Fukuda, T. Suezaki, M. Ichikawa, Y. Koi, M. Goto, T. Meguro, T. Matsuda, M. Kondo, T. Sasaki, and Y. Tawada, Sol. Energy 77, 939 (2004).

${ }^{11}$ J. Yang, A. Banerjee, and S. Guha, Appl. Phys. Lett. 70, 2975 (1997).

${ }^{12}$ T. Soderstrom, F. J. Haug, V. Terrazzoni-Daudrix, X. Niquille, M. Python, and C. Ballif, J. Appl. Phys. 104, 104505 (2008).

${ }^{13}$ T. Söderström, F. J. Haug, V. Terrazzoni-Daudrix, and C. Ballif, J. Appl. Phys. 103, 114509 (2008).

${ }^{14}$ R. H. Franken, R. L. Stolk, H. Li, C. H. M. van der Werf, J. K. Rath, and R. E. I. Schropp, J. Appl. Phys. 102, 014503 (2007).

${ }^{15}$ A. Banerjee and S. Guha, J. Appl. Phys. 69, 1030 (1991).

${ }^{16}$ J. Steinhauser, S. Faÿ, N. Oliveira, E. Vallat-Sauvain, and C. Ballif, Appl. Phys. Lett. 90, 142107 (2007).

${ }^{17}$ J. Meier, U. Kroll, E. Vallat-Sauvain, J. Spitznagel, U. Graf, and A. Shah, Sol. Energy 77, 983 (2004).

${ }^{18}$ P. Obermeyer, C. Haase, and H. Stiebig, Appl. Phys. Lett. 92, 181102 (2008) 